\title{
Dimensi Tubuh Sapi Friesian Holstein dan Limousin Betina Berdasarkan Morfometrik dengan Citra Digital
}

\author{
Body Dimension of Friesian Holstein and Limousin Cows Based on Morphometric Using Digital Image \\ Analysis
}

A. Hakim ${ }^{1}$, H. Nuraini ${ }^{1}$, R. Priyanto ${ }^{1}$, \& T. Harsi ${ }^{2}$

${ }^{1}$ Departemen Ilmu Produksi dan Teknologi Peternakan, Fakultas Peternakan, IPB

Jalan Agatis, Kampus IPB Dramaga, Bogor 16680, Indonesia

${ }^{2}$ Balai Embrio Ternak (BET), Cipelang, Bogor

Kel. Cipelang, Kec. Cijeruk, Kab. Bogor 16004, Indonesia

Email koresponden author: annisa.hakim13@gmail.com

\begin{abstract}
Digital image analysis have been applied to determine and follow the body measurement, live weights, and animal growth. The objectives on this study were to compare linear body measurement (BMs) method (manually and digital image analysis) and to compare size and body dimension of Friesian Holstein (FH) and Limousin cows. In this study, the BMs of FH and Limousin cows was determined using digital image analysis (IA). Linear measurement of primary morphometrics, part of Columna vertebralis, and extrimity length of cows was first determined manually, by direct measurement. Then the digital images of cows were taken and the results obtained through the calculations were recorded into the computer and analized by Corel draw. Result showed that the BMs with both methods measurement was not significant different and IA method had lower coefficient variation (CV) than manual, which indicates the IA method can be used for morphometric study. For the body dimension, FH had larger frame size and lower body weight than Limousin. The different of breed caused differences in morphometric performances. FH had longer thoraxoc vertebrae, wither height, space between ischium, and space coxae to ischium than Limousin. Limousin had longer cervicalis vertebrae, sacral vertebrae, and scapulla.
\end{abstract}

Keywords: body dimension, digital image analysis, Friesian Holstein, Limousin, morphometric

\section{PENDAHULUAN}

Penilaian secara fisik merupakan bagian yang penting dalam proses seleksi. Hal tersebut dapat menjadi indikator yang baik dalam menentukan frame size, struktur otot dan tubuh, struktur kaki, dan karakteristik dari suatu bangsa sapi (Barham et al. 2005). Lawrance et al. (2012) menyatakan bahwa terdapat tiga metode dalam pengukuran dan pendugaan bobot hidup serta perubahan konformasi tubuh ternak, diantaranya penimbangan langsung, pengukuran parameter tubuh, dan melalui analisis video dan gambar. Pada penelitian ini dilakukan tiga metode pengukuran pertumbuhan tersebut pada sapi dengan ukuran kerangka tubuh besar (Bos taurus), yaitu Friesian Holstein dan Limousin. Sapi dengan ukuran kerangka tubuh yang besar memiliki produktivitas yang tinggi. Ukuran kerangka yang besar memiliki bobot potong yang besar dan memungkinkan tempat berkembangnya daging yang lebih luas sehingga produktivitas yang dihasilkan tinggi.

Pengukuran dimensi tubuh ternak biasanya dilakukan secara langsung dengan menggunakan alat ukur berupa tongat ukur, pita ukur dan jangka ukur. Pengukuran bagian-bagian permukaan tubuh tersebut diambil ketika hewan dalam kondisi berdiri normal dengan kepala tegak dan bobot badan bertumpu pada keempat kakinya. Menurut Fisher (1975), terdapat tiga hal yang dapat menjadi sumber eror dalam pengukuran tubuh ternak, yaitu: (1) identifikasi dalam penentuan titik tubuh yang akan diukur; (2) distorsi anatomi tubuh yang dihasilkan oleh ternak yang mengubah posisi atau posturnya atau dikarenakan perubahan otot; dan (3) eror yang disebabkan pada saat pengukuran pada berbagai posisi tubuh ternak, yang banyak terjadi saat menggunakan pita ukur. Oleh karena itu, pengukuran dimensi tubuh pada penelitian ini selain dilakukan secara langsung (manual) juga dilakukan melalui analisis gambar (citra digital) untuk mengurangi eror tersebut.

Citra adalah istilah lain dari gambar yang merupakan informasi berbentuk visual. Pengambilan citra bisa dilakukan oleh kamera atau alat lain yang bisa digunakan untuk mentransfer gambar. Data yang dihasilkan oleh 
suatu citra harus dilakukan pengolahan informasi dan analisis yang banyak melibatkan persepsi visual dengan computer vision. Computer vision merupakan ilmu yang memungkinkan informasi dalam suatu gambar dapat dihasilkan dari pengolahan komputer secara teoritis dengan menggunakan algoritma. Analisis gambar dengan metode ini memiliki banyak kelebihan, diantaranya menghemat waktu, keakuratan dan ekonomis. Penelitian mengenai citra digital yang berkaitan dengan bidang peternakan telah banyak dilakukan, dalam hal ini metode yang digunakan melibatkan analisis tekstur atau piksel dalam suatu gambar yang diolah menggunakan algoritma perhitungan komputer (computer vision) (Tasdemir et al. 2011).

Penelitian Tasdemir et al. (2011) melakukan pengukuran dimensi tubuh dan pendugaan bobot badan sapi FH dengan menggunakan teknik pengukuran digital (photogrammetry), yaitu melalui foto jarak dekat dengan pengambilan secara berganda dari perspektif yang berbeda untuk menghasilkan model 3D yang akurat dan diolah menggunakan IA software. Hasil penelitian tersebut menunjukkan keakuratan metode untuk pengukuran dimensi tubuh 95-98\%. Penelitian lain yang menggunakan metode tersebut diantaranya identifikasi kesegaran daging sapi (Kiswanto 2012), pendugaan bobot badan sapi (Lasfeto et al. 2008), klasifikasi jenis-jenis tekstur dan identifikasi warna daging sapi dan babi (Budianita et al. 2015), dan pendugaan genetik komposisi karkas dengan analisis gambar (Pabiou et al. 2011). Selain itu, penelitian citra digital juga dilakukan untuk mengukur dimensi tubuh sapi dan pendugaan bobot badan dengan menggunakan infrared thermal camera (Stajnko et al. 2008).

Sistem analisis gambar pada penelitian ini berdasar pada penggunaan kombinasi kamera dan komputer, yaitu melalui pengambilan gambar sapi dan menganalisis parameter tubuhnya dengan software corel draw. Prinsip metode ini adalah dengan mengambil foto digital dari ternak pada jarak tertentu menggunakan kamera digital sehingga didapatkan foto ternak full frame dengan menggunakan tongkat pembanding. Ternak yang akan diambil gambarnya ditempatkan pada area yang datar dan lurus sehingga dapat diambil gambar seluruh tubuh dan diletakkan tongkat pembanding sejajar dengan kaki. Gambar diambil dari samping dan belakang tegak lurus tubuh ternak.

Munoz-Munoz dan Perpinan (2010) membandingkan pengukuran manual dan komputerisasi dalam studi morfometrik. Hasil penelitian tersebut menunjukkan bahwa pengukuran morfometrik dengan komputerisasi memberikan pengaruh yang rendah dalam peningkatan standar eror daripada pengukuran manual, dengan dilakukannya metode citra digital pada pengukuran tubuh ternak sapi diharapkan dapat memberikan metode yang praktis dan akurat dalam penilaian ukuran tubuh ternak serta untuk meminimalisir eror yang dihasilkan dari pengukuran manual. Penelitian ini bertujuan membandingkan karakteristik ukuran tubuh sapi Friesian Holstein dan Limousin dengan pengukuran manual dan digital.

\section{MATERI DAN METODE}

\section{Waktu dan Tempat Penelitian}

Penelitian ini dilaksanakan pada bulan Februari sampai dengan Mei 2015. Pengukuran dimensi tubuh dan pengambilan foto sapi Friesian Holstein dan Limousin dilaksanakan di Balai Embrio Ternak (BET) Cipelang Bogor.

\section{Materi Penelitian}

Materi yang digunakan pada penelitian ini adalah sapi Friesian Holstein dan Limousin betina dengan berbagai tingkat umur, masing-masing sebanyak 53 dan 71 ekor sapi dengan rincian jumlah sapi dapat dilihat pada Tabel 1. Alat yang digunakan pada penelitian ini adalah tongkat ukur (ketelitian $1 \mathrm{~cm}$ ), pita ukur Rondo, tongkat pembanding (1 $\mathrm{m})$, kamera Nikon D3200, timbangan digital, alat tulis dan laptop yang dilengkapi dengan software Corel Draw.

Tabel 1. Jumlah sapi betina yang digunakan dalam penelitian

\begin{tabular}{lccc}
\hline Jenis sapi & Pedet & Dara & Dewasa \\
\cline { 2 - 4 } & $(0-7$ bulan $)$ & $(8-18$ bulan $)$ & $(>18$ bulan $)$ \\
\hline Friesian Holstein & 17 & 12 & 24 \\
Limousin & 17 & 20 & 34 \\
\hline
\end{tabular}

\section{Prosedur Penelitian}

Penelitian ini dilakukan diawali dengan penentuan umur sapi berdasarkan hasil recording, penimbangan sapi, pengukuran dimensi panjang tubuh secara manual, pengambilan foto sapi, dan analisis foto. Prosedur penimbangan, pengukuran secara manual dan pengambilan foto dapat dilakukan secara bersamaan di dalam kandang jepit atau dilakukan secara terpisah satu per satu.

Pengukuran sapi secara manual dilakukan menggunakan tongkat dan pita ukur. Sapi yang diukur ditempatkan pada kandang jepit untuk memudahkan pengukuran. Apabila tidak dimasukkan kandang jepit, sapi dalam kandang koloni yang tidak terikat harus diikat terlebih dahulu untuk memudahkan handling saat pengukuran. Pengukuran sapi secara digital diawali dengan pengambilan gambar sapi. Sapi yang difoto ditempatkan pada area yang datar dan lurus sehingga dapat diambil gambar seluruh tubuh secara jelas. Gambar diambil dari samping dan belakang tegak lurus tubuh ternak dengan tongkat pembanding yang berada di samping tubuhnya.

Kemudian dari hasil pencitraan tersebut dilakukan pengukuran parameter morfometrik. Pengukuran parameter ukuran tubuh dianalisis dengan menggunakan Corel Draw $X 4$, yaitu dengan mengukur panjang tongkat pembanding dengan masing-masing ukuran tubuh ternak yang kemudian akan dikalkulasikan secara matematis. Penggunaan software Corel Draw X4 dipilih karena dapat melakukan perbesaran gambar yang proporsional tanpa terjadi perubahan perbandingan proporsi dari gambar tersebut. Selain itu, software ini dapat melakukan rotasi gambar yang lebih halus, sehingga detail dan hasil pengukuran dapat lebih akurat. Adapun tahapan dari pengukurannya adalah sebagai berikut: 
1. Launch aplikasi Corel Draw X4 Blank Document

2. Import foto sapi yang akan diukur

3. Klik Freehand Tool (a) aplikasikan pada tongkat ukur dari ujung atas ke ujung bawah

4. Drag hasil pengukuran tongkat ke blank space (b)

5. Lihat hasil pengukuran panjang tongkat pada kolom Object(s) size (c)

6. Buat rumus phytagoras dan perkalian silang pada program aplikasi Excel

7. Pindahkan angka yang terdapat pada Object(s) size (c) ke program Excel untuk mengetahui nilai objek pada foto dibandingkan dengan panjang objek sebenarnya (untuk tongkat pembanding)

8. Ulangi prosedur tersebut untuk mengukur parameter tubuh lainnya

Pengukuran morfometrik yang diamati, diantaranya (Gambar 1):

1. Panjang kelompok tulang Cervicalis vertebrae. Diukur dari batas Axio-Atlas hingga pangkal leher bagian dorsal. Pada sapi yang berpunuk diukur tepat di depan punuk.

2. Panjang kelompok tulang Thoracic vertebrae. Diukur dari pangkal leher hingga titik tengah tubuh bagian dorsal.

3. Panjang kelompok tulang Lumbar vertebrae. Diukur dari titik tengah tubuh bagian dorsal hingga Processus spinosus pertama tulang Sacrum.

4. Panjang kelompok tulang Sacral vertebrae. Diukur di sepanjang tulang sacrum.

5. Panjang tulang Scapulla. Diukur dari titik tertinggi tubuh (untuk sapi berpunuk diukur dari pangkal punuk) hingga Tuber humerus.

6. Panjang tulang Humerus. Diukur dari Tuber humerus hingga di titik tengah Tuber radius-ulna

7. Panjang tulang Radius-Ulna. Diukur dari Tuber radius-ulna hingga Os carpal.

8. Panjang tulang Metacarpus. Diukur dari Os carpal hingga pangkal Os Phalank 1.

9. Panjang tulang Femur. Diukur dari Tuber illium hingga Tuber femoris.

10. Panjang tulang Tibia-Fibulla. Diukur dari Tuber femoris hingga Tuber calcis

11. Panjang tulang Metatarsal. Diukur dari pangkal $O s$ tarsus hingga Os phalank 1.

12. Panjang badan. Diukur dari Tuber humerus hingga Tuber ischium.

13. Tinggi badan. Diukur tepat di belakang Os scapulla dari titik dorsal hingga tanah.

14. Dalam dada. Diukur tepat di belakang Os scapulla dari titik dorsal hingga ventral.

15. Tinggi hip. Diukur lurus dari Os Coxae hingga tanah.

16. Jarak antar Coxae. Diukur dari Tuber coxae kiri dan Tuber coxae kanan.

17. Jarak antar Ischium. Diukur dari Tuber ischium kiri dan Tuber ischium kanan.

18. Jarak Coxae-Ischium. Diukur dari Tuber coxae kiri dan Tuber ischium kanan

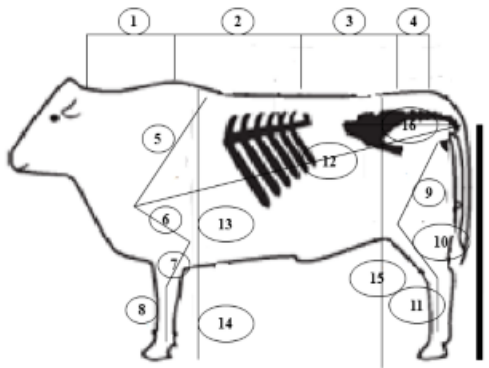

(a)

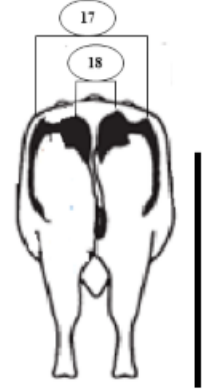

(b)
Gambar 1. Contoh pengambilan foto dan pengukuran parameter tubuh sapi. (a) tampak samping; dan (b) tampak belakang

\section{Analisis Data}

Data hasil penelitian dianalisis secara deskriptif, yaitu dengan rataan, standar deviasi, dan koefisien keragaman. Pengukuran manual dan digital dianalisis dengan uji t-student, dengan rumus matematis menurut Stell dan Torrie (1991) adalah sebagai berikut:

$$
t=\frac{(X a-X b)-(\mu a-\mu b)}{S x a-x b}
$$

Keterangan :

$\mathrm{t} \quad$ : Nilai $\mathrm{t}$ hitung yang akan dibandingkan dengan $\mathrm{t}$ tabel untuk menentukan penerimaan hipotesis

$(X a-X b)$ : Selisih rata-rata sampel a dan b

$(\mu a-\mu b)$ : Selisih rata-rata populasi a dan b

$S x a-x b$ : Nilai standar eror

Nilai frame score dihitung berdasarkan tinggi hip berdasarkan metode BIF (2002), yaitu membandingkan antara ukuran tinggi hip sapi betina pada umur 5-21 bulan. Analisis data dilakukan dengan prosedur "general linear model" pada program SAS 9.1.3.

\section{HASIL DAN PEMBAHASAN}

\section{Perbandingan Metode Pengukuran Dimensi Tubuh Sapi Secara Manual dan Menggunakan Analisis Gambar (Citra Digital)}

Pengukuran dimensi tubuh ternak biasanya dilakukan secara langsung dengan menggunakan alat ukur berupa tongat ukur, pita ukur dan jangka ukur. Pengukuran bagianbagian permukaan tubuh tersebut diambil ketika hewan dalam kondisi berdiri normal dengan kepala tegak dan bobot badan bertumpu pada keempat kakinya. Kelebihan dari pengukuran secara manual adalah data yang dihasilkan langsung diperoleh tanpa harus mengolah terlebih dahulu. Pengukuran secara manual ini akan efektif bila dilakukan pada ternak dengan jumlah yang sedikit dan ternak yang memiliki agonistik rendah (tempramen tenang). Fisher (1975) menjelaskan terdapat tiga hal yang dapat menjadi sumber eror dalam pengukuran tubuh ternak, yaitu: (1) identifikasi dalam penentuan titik tubuh yang akan diukur; (2) distorsi anatomi tubuh yang dihasilkan oleh ternak yang mengubah posisi atau posturnya atau dikarenakan perubahan 
otot; dan (3) eror yang disebabkan pada saat pengukuran pada berbagai posisi tubuh ternak, yang banyak terjadi saat menggunakan pita ukur. Oleh karena itu, pengukuran dimensi tubuh pada penelitian ini selain dilakukan secara langsung (manual) juga dilakukan melalui analisis gambar (citra digital) untuk mengurangi eror tersebut.

Sistem analisis gambar pada peneitian ini dilakukan dengan sederhana, yaitu melalui pengambilan gambar sapi dan menganalisis parameter tubuhnya dengan software untuk menganalisis gambar (corel draw). Prinsip metode ini adalah dengan mengambil foto digital dari ternak pada jarak tertentu menggunakan kamera digital sehingga didapatkan foto ternak full frame dengan menggunakan tongkat pembanding. Ternak yang akan diambil gambarnya ditempatkan pada area yang datar dan lurus sehingga dapat diambil gambar seluruh tubuh dan diletakkan tongkat pembanding sejajar dengan kaki. Gambar diambil dari samping tegak lurus tubuh ternak. Tongkat pembanding dalam hal ini berfungsi sebagai penentu ukuran objek sebenarnya saat dilakukan perhitungan secara matematis sederhana. Kamera yang digunakan dalam penelitian ini dapat berupa kamera handphone, pocket, atau DSLR karena tidak membutuhkan spesifikasi yang tinggi seperti pada penelitian citra digital dengan analisis tekstur, piksel, dan diolah dengan algoritma.

Pengukuran tubuh secara langsung (manual) dilakukan dan hasilnya dibandingkan dengan pengukuran melalui analisis gambar (citra digital) untuk mengetahui keakuratan metode pengukuran digital. Hal ini dilakukan agar dapat digunakan dalam mempermudah dan meminimalkan resiko yang disebabkan dari pengukuran manual, karena objek yang digunakan dalam pengukuran morfometrik adalah hewan hidup yang memiliki karakteristik agonistik yang berbeda. Perbandingan metode pengukuran dimensi tubuh sapi dilakukan pada sapi dewasa karena sapi dewasa cenderung lebih tenang dan stabil saat dilakukan pengambilan gambar sehingga gambar yang dihasilkan baik (pada posisi yang tegak). Selain itu, pada sapi pedet dan dara lebih mudah dilakukan pengukuran secara manual karena masih mudah dilakukan handling dan tidak bahaya saat dilakukan pengukuran. Hasil analisis perbandingan metode pengukuran dimensi tubuh sapi FH dan Limousin betina dewasa secara manual dan digital ditunjukkan pada Tabel 2.

Data pada Tabel 2 menunjukkan bahwa metode pengukuran dimensi tubuh secara manual dan digital tidak menunjukkan perbedaan yang nyata. Selain itu, sebagian besar hasil pengukuran dimensi tubuh dengan metode citra digital memiliki nilai standar deviasi dan koefisien keragaman yang lebih rendah dibandingkan pada metode manual, dengan demikian tingkat keakuratan pada metode digital lebih tinggi daripada manual. Hasil tersebut sesuai dengan pendapat Munoz-Munoz dan Perpinan (2010), yaitu pengukuran morfometrik dengan komputerisasi memberikan pengaruh yang rendah dalam peningkatan standar eror daripada pengukuran manual. Menurut Tasdemir et al. (2011) photogrammetry (mengukur objek dari foto) merupakan teknik yang akurat dalam teknik pengukuran objek. Jika dibandingkan dengan teknik manual, photogrammetry lebih efisien, cepat, dan aman. Data pada Tabel 2 juga menunjukkan koefisien keragaman pada pengukuran manual sapi FH lebih tinggi daripada Limousin. Hal ini dikarenakan pada saat dilakukan pengukuran secara manual, pergerakan sapi $\mathrm{FH}$ lebih tinggi daripada sapi Limousin sehingga lebih sulit dilakukan. Dengan demikian, pengukuran secara digital dapat dilakukan untuk menggantikan pengukuran manual sehingga metode ini dapat diaplikasikan dalam penelitian morfometrik yang melibatkan ternak yang memiliki agresifitas yang berbeda.

Pengukuran morfometrik dengan metode citra digital ini memiliki kelebihan dibandingkan dengan pengukuran manual, diantaranya: (1) dapat memperkecil resiko ternak stress selama pengukuran, (2) memperkecil resiko keselamatan peneliti akibat serangan ternak yang agresif, (3) pelaksanaan di kandang lebih cepat, karena handling tidak membutuhkan waktu yang lama, (4) hasil pengukuran memiliki tingkat keakuratan yang lebih tinggi, dan (5) dapat mengurangi eror yang dapat disebabkan oleh pengukuran manual menurut Fisher (1975). Menurut Tasdemir et al. (2011), masalah dalam biaya, kesulitan dalam pengukuran, keterbatasan personel, resiko dan stress pada ternak dapat diatasi dengan metode pengukuran digital.

Kelemahan dari metode ini adalah hanya dapat merepresentasikan gambar dua dimensi, sehingga data yang didapatkan adalah panjang, lebar dan tinggi, tidak dapat mengukur parameter yang berupa lingkar. Kelemahan pada metode ini juga pada saat pengambilan gambar posisi ternak harus tegak lurus dengan posisi kamera dan tongkat pembanding harus sejajar dengan tubuh ternak, sehingga untuk ternak yang memiliki tingkat agonistik tinggi dan tidak dikandangkan sulit dilakukan karena sulit untuk memposisikan tongkat pembanding tersebut. Selain itu, untuk melakukan pengukuran tubuh ternak secara digital harus memiliki kemampuan dalam menentukan titik-titik bagian tubuh yang akan diukur karena apabila titik ukur tersebut tidak sesuai, ukuran yang dihasilkan tidak akan akurat. Keakuratan pengukuran secara digital ini dapat ditentukan oleh karakteristik dari ternak yang akan diukur. Metode ini sulit dilakukan pada ternak yang memiliki rambut tebal, warna gelap, dan gemuk, karena hal tersebut dapat menjadi penghambat dalam menentukan titik tubuh ternak (tonjolan tulang).

\section{Karakteristik Morfologi Sapi FH dan Limousin Betina}

Hasil pengukuran bobot badan, panjang badan, tinggi badan, dan dalam dada sapi dapat dilihat pada Gambar 2. Sedangkan hasil pengukuran performa morfometrik dengan analisa citra digital dapat dilihat pada Tabel 3. Rataan bobot badan sapi Limousin lebih tinggi $(643,17 \pm 36,33 \mathrm{~kg})$ daripada sapi FH $(507,09 \pm 62,99 \mathrm{~kg})$. Gambar 2 menunjukkan bahwa perbedaan kenaikan bobot badan mulai terlihat sejak sapi berumur 7 bulan. Hammack dan Gill (2009) menjelaskan bahwa ukuran tubuh dan bobot tubuh saling berhubungan, namun terdapat perbedaan dalam mencapai tingkat kedewasaannya. Pada umur 7 bulan, tinggi sapi telah mencapai $80 \%$, sedangkan bobot sapi baru tercapai $35-40 \%$. Sapi pada umur 12 bulan mencapai tinggi $90 \%$, sedangkan bobot baru tercapai 50-60\%. 
Hakim et al.

Jurnal Ilmu Produksi dan Teknologi Hasil Peternakan 7 (2): 47-56

Tabel 2. Perbandingan nilai pengukuran morfometrik sapi FH dan Limousin betina dewasa dengan metode pengukuran secara manual dan digital

\begin{tabular}{|c|c|c|c|c|c|c|c|c|}
\hline \multirow[t]{2}{*}{ Parameter } & \multicolumn{3}{|c|}{$\mathrm{FH}$} & \multicolumn{4}{|c|}{ Limousin } & \multirow[b]{2}{*}{$\begin{array}{l}\text { KK } \\
(\%)\end{array}$} \\
\hline & $\begin{array}{c}\text { Manual } \\
(\mathrm{cm})\end{array}$ & $\begin{array}{l}\text { KK } \\
(\%)\end{array}$ & $\begin{array}{l}\text { Digital } \\
(\mathrm{cm})\end{array}$ & $\begin{array}{l}\text { KK } \\
(\%)\end{array}$ & $\begin{array}{c}\text { Manual } \\
(\mathrm{cm})\end{array}$ & $\begin{array}{l}\text { KK } \\
(\%)\end{array}$ & $\begin{array}{l}\text { Digital } \\
(\mathrm{cm})\end{array}$ & \\
\hline \multicolumn{9}{|l|}{ Sumbu Tubuh } \\
\hline Cervicalis vertebrae & $41,56 \pm 4,96$ & 11,93 & $36,92 \pm 3,02$ & 8,17 & $43,92 \pm 2,62$ & 5,96 & $42,36 \pm 1,81$ & 4,26 \\
\hline Thoraxic vertebrae & $59,76 \pm 8,14$ & 13,62 & $57,18 \pm 4,74$ & 8,29 & $54,29 \pm 3,59$ & 6,62 & $54,94 \pm 3,08$ & 5,61 \\
\hline Lumbar vertebrae & $41,96 \pm 6,80$ & 16,20 & $40,97 \pm 3,86$ & 9,41 & $43,50 \pm 4,23$ & 9,73 & $44,23 \pm 2,98$ & 6,75 \\
\hline Sacral vertebrae & $20,52 \pm 2,06$ & 10,06 & $20,98 \pm 1,28$ & 6,11 & $22,29 \pm 2,24$ & 10,02 & $21,76 \pm 2,11$ & 9,67 \\
\hline \multicolumn{9}{|l|}{ Alat Gerak Depan } \\
\hline Scapulla & $49,52 \pm 7,32$ & 14,77 & $48,49 \pm 4,65$ & 9,59 & $50,88 \pm 3,39$ & 6,67 & $49,94 \pm 2,70$ & 5,40 \\
\hline Humerus & $39,48 \pm 3,70$ & 9,37 & $38,76 \pm 3,26$ & 8,40 & $40,95 \pm 4,04$ & 9,88 & $38,48 \pm 3,65$ & 9,48 \\
\hline Radius-Ulna & $38,48 \pm 4,80$ & 12,47 & $39,22 \pm 3,26$ & 8,40 & $37,38 \pm 3,37$ & 9,23 & $36,41 \pm 3,33$ & 9,15 \\
\hline Metacarpus & $26,40 \pm 3,03$ & 11,49 & $24,25 \pm 2,09$ & 8,62 & $23,46 \pm 2,54$ & 10,81 & $22,75 \pm 1,99$ & 8,73 \\
\hline \multicolumn{9}{|l|}{ Alat Gerak Belakang } \\
\hline Femur & $47,80 \pm 4,99$ & 10,44 & $47,45 \pm 4,66$ & 9,82 & $50,42 \pm 4,07$ & 8,08 & $50,43 \pm 3,91$ & 7,75 \\
\hline Tibia-Fibula & $46,32 \pm 4,85$ & 10,45 & $44,97 \pm 4,00$ & 8,91 & $46,12 \pm 3,93$ & 8,51 & $46,81 \pm 3,18$ & 6,80 \\
\hline Metatarsus & $32,96 \pm 4,20$ & 11,47 & $28,55 \pm 2,87$ & 10,05 & $37,08 \pm 2,90$ & 7,83 & $36,53 \pm 2,72$ & 7,47 \\
\hline \multicolumn{9}{|l|}{ Performa Umum } \\
\hline Panjang Badan & $155,84 \pm 17,07$ & 10,95 & $157,07 \pm 16,55$ & 10,54 & $160,75 \pm 17,49$ & 10,88 & $156,26 \pm 13,37$ & 8,56 \\
\hline Tinggi Badan & $138,56 \pm 12,11$ & 8,74 & $136,58 \pm 11,92$ & 8,72 & $133,75 \pm 8,52$ & 6,37 & $134,68 \pm 7,76$ & 5,76 \\
\hline Tinggi Hip & $139,84 \pm 10,17$ & 7,27 & $138,44 \pm 9,92$ & 7,17 & $140,12 \pm 8,59$ & 6,13 & $140,70 \pm 7,77$ & 5,52 \\
\hline Dalam dada & $76,40 \pm 7,52$ & 9,84 & $75,92 \pm 7,14$ & 9,40 & $72,25 \pm 6,24$ & 8,63 & $71,72 \pm 5,54$ & 7,72 \\
\hline Jarak antar Coxae & $53,12 \pm 5,13$ & 9,65 & $53,75 \pm 4,47$ & 8,32 & $49,54 \pm 4,98$ & 10,05 & $47,49 \pm 4,22$ & 8,88 \\
\hline Jarak antar Ischium & $22,44 \pm 3,83$ & 17,07 & $22,53 \pm 3,03$ & 13,44 & $19,88 \pm 2,47$ & 12,44 & $18,97 \pm 1,39$ & 7,33 \\
\hline Jarak Coxae-Ischium & $51,64 \pm 4,90$ & 9,48 & $51,95 \pm 5,21$ & 10,04 & $47,46 \pm 3,65$ & 7,68 & $47,27 \pm 3,32$ & 7,02 \\
\hline
\end{tabular}
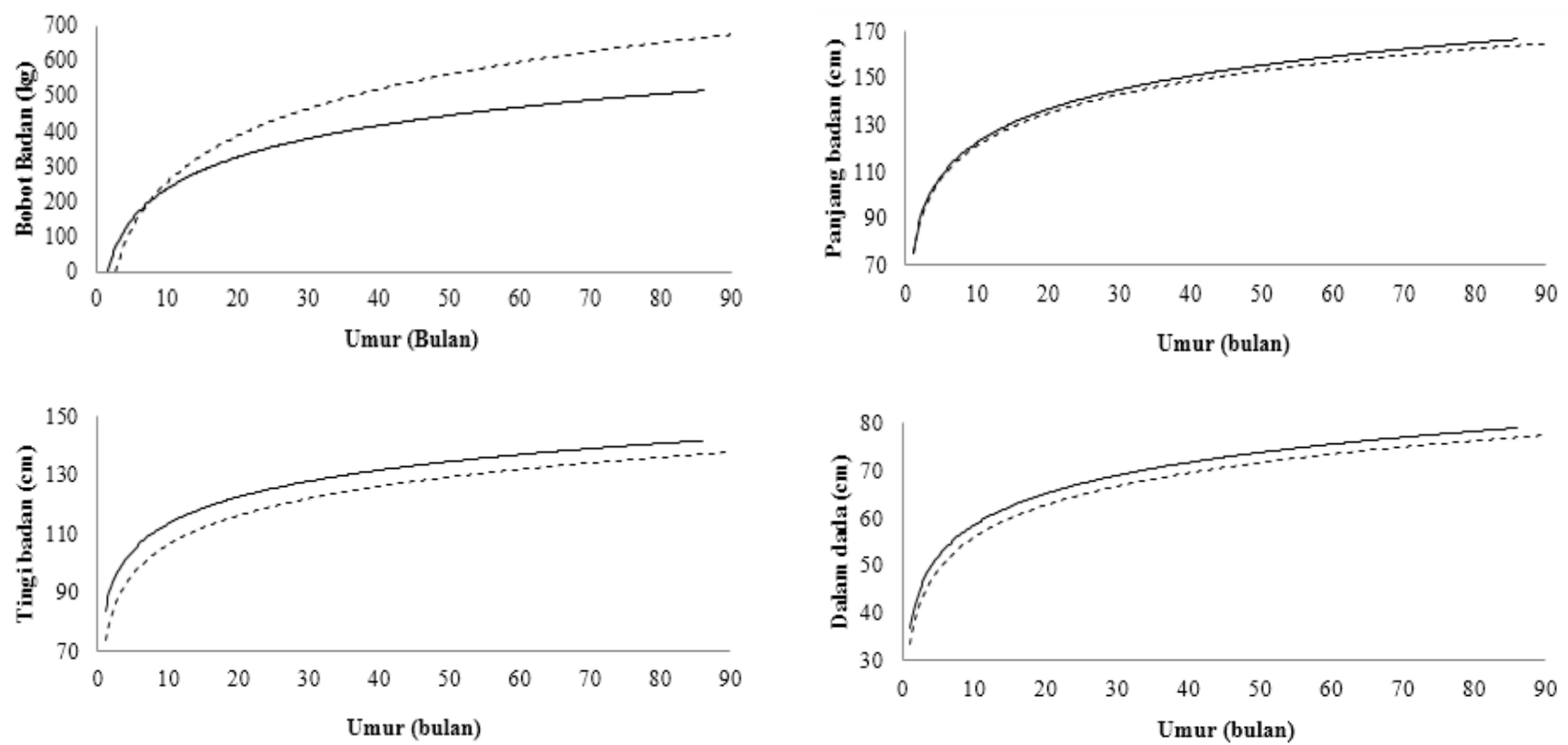

Gambar 2. Diagram scatter pertumbuhan bobot badan, panjang badan, tinggi badan, dan dalam dada sapi FH (—) dan Limousin (----) betina 
Peningkatan ukuran tubuh akan menyebabkan peningkatan yang proporsional dari bobot tubuh, karena bobot tubuh merupakan fungsi dari volume. Namun berdasarkan hasil penelitian pada Gambar 2 menunjukkan bahwa bobot badan sapi Limousin lebih tinggi daripada sapi FH, sedangkan nilai ukuran tubuh dominan lebih tinggi pada sapi FH. Hal ini membuktikan bahwa bobot badan tidak dapat ditentukan oleh ukuran tubuh, karena banyak faktor yang dapat mempengaruhi bobot badan. Faktor tersebut diantaranya terdapat perbedaan ketebalan otot, lingkar dan kepadatan tulang, serta komponen non-karkas sapi (seperti komposisi organ dalam, darah, dan kulit).

Sapi FH dan Limousin pada penelitian ini memiliki perbedaan bobot badan yang cukup tinggi, padahal proporsi pakan yang diberikan sama. Hal ini dapat disebabkan perbedaan fungsi fisiologis dari kedua bangsa sapi tersebut. Sapi FH yang merupakan tipe perah, pakan tidak terdeposisi menjadi daging, sehingga sapi FH cenderung kurus. Perbedaan perlakuan pakan tidak berpengaruh terhadap proporsi tulang yang dihasilkan. Berg dan Butterfield (1976) melakukan penelitian mengenai pengaruh rencana pemberian nutrisi terhadap komposisi karkas sapi steer. Parameter yang diamati adalah persentase komposisi karkas yang diberi perlakuan pemberian pakan yang memiliki tingkat nutrisi dari sedang ke tinggi. Hasil penelitian tersebut menunjukkan bahwa bobot tulang pada setiap perlakuan tidak memberikan perbedaan yang nyata, sedangkan persentase otot dan lemak pada setiap perlakuan berbeda nyata. Selain itu, persentase distribusi tulang pada bagian tubuh depan dan belakang tidak berbeda antara sapi bull dengan steer. Penelitian lain menyatakan bahwa proporsi tulang babi yang diberi perlakuan pakan yang berbeda menunjukkan ukuran tulang yang normal (Lawrance dan Fowler 2002).

Data pada Tabel 3 merupakan ukuran tubuh pada sapi betina dewasa. Sapi betina dewasa harus dilakukan pengafkiran yang disebabkan oleh beberapa hal, sebagian dari sapi afkir tersebut langsung disembelih (dikarenakan luka atau penyakit) ataupun digemukkan terlebih dahulu sebelum penyembelihan (Phillips 2010). Sapi perah betina dewasa pada umumnya dilakukan pengafkiran pada usia 5-6 tahun (Campbell et al. 2005), sedangkan umur afkir sapi Limousin betina di atas 3 tahun, dengan rataan bobot karkas mencapai 58,33\%. Sapi betina Limousin mencapai perkembangan morfologi secara penuh pada umur 6-8 tahun dan konstan sampai umur 10-12 tahun. Secara umum, persentase karkas pada sapi betina afkir adalah $44-55 \%$, dengan proporsi tulang $17-32 \%$, lemak $7-30 \%$ dan otot

Tabel 3. Rataan dimensi tubuh sapi FH dan Limousin betina dewasa

\begin{tabular}{|c|c|c|c|c|}
\hline Parameter & $\begin{array}{l}\mathrm{FH} \\
(\mathrm{cm})\end{array}$ & $\begin{array}{l}\text { KK } \\
(\%)\end{array}$ & $\begin{array}{l}\text { Limousin } \\
\text { (cm) }\end{array}$ & $\begin{array}{l}\text { KK } \\
(\%)\end{array}$ \\
\hline \multicolumn{5}{|l|}{ Sumbu Tubuh } \\
\hline Cervicalis vertebrae & $36,92 \pm 3,02 \mathrm{a}$ & 8,17 & $42,36 \pm 1,81 b$ & 4,26 \\
\hline Thoraxic vertebrae & $57,18 \pm 4,74 \mathrm{a}$ & 8,29 & $54,94 \pm 3,08 b$ & 5,61 \\
\hline Lumbar vertebrae & $40,97 \pm 3,86$ & 9,41 & $44,23 \pm 2,98$ & 6,75 \\
\hline Sacral vertebrae & $20,98 \pm 1,28 \mathrm{a}$ & 6,11 & $21,76 \pm 2,11 b$ & 9,67 \\
\hline \multicolumn{5}{|l|}{ Alat Gerak Depan } \\
\hline Scapula & $48,49 \pm 4,65 \mathrm{a}$ & 9,59 & $49,94 \pm 2,70 b$ & 5,40 \\
\hline Humerus & $38,76 \pm 3,26$ & 8,40 & $38,48 \pm 3,65$ & 9,48 \\
\hline Radius-Ulna & $39,22 \pm 3,26$ & 8,40 & $36,41 \pm 3,33$ & 9,15 \\
\hline Metacarpus & $24,25 \pm 2,09$ & 8,62 & $22,75 \pm 1,99$ & 8,73 \\
\hline \multicolumn{5}{|l|}{ Alat Gerak Belakang } \\
\hline Femur & $47,45 \pm 4,66$ & 9,82 & $50,43 \pm 3,91$ & 7,75 \\
\hline Tibia-Fibula & $44,97 \pm 4,00$ & 8,91 & $46,81 \pm 3,18$ & 6,80 \\
\hline Metatarsus & $28,55 \pm 2,87$ & 10,05 & $36,53 \pm 2,72$ & 7,47 \\
\hline \multicolumn{5}{|l|}{ Performa Umum } \\
\hline Jarak antar Coxae & $53,75 \pm 4,47$ & 8,32 & $47,49 \pm 4,22$ & 8,88 \\
\hline Jarak antar Ischium & $22,53 \pm 3,03 \mathrm{a}$ & 13,44 & $18,97 \pm 1,39 b$ & 7,33 \\
\hline Jarak Coxae-Ischium & $51,95 \pm 5,21 \mathrm{a}$ & 10,04 & $47,27 \pm 3,32 b$ & 7,02 \\
\hline Panjang Badan & $157,07 \pm 16,55$ & 10,54 & $156,26 \pm 13,37$ & 8,56 \\
\hline Dalam dada & $75,92 \pm 7,14$ & 9,40 & $71,72 \pm 5,54$ & 7,72 \\
\hline Tinggi Badan & $136,58 \pm 11,92 \mathrm{a}$ & 8,72 & $134,68 \pm 7,76 b$ & 5,76 \\
\hline Tinggi Hip & $138,44 \pm 9,92$ & 7,17 & $140,70 \pm 7,77$ & 5,52 \\
\hline Tinggi Hip 5-21 bulan & $47,22 \pm 2,77$ & 5,87 & $44,82 \pm 4,09$ & 9,12 \\
\hline Frame Score & $6,06 \pm 0,81$ & 13,37 & $5,06 \pm 0,95$ & 18,78 \\
\hline
\end{tabular}

Keterangan: Superkrip berbeda pada baris yang sama menunjukkan perbedaan yang nyata $(\mathrm{P}<0,05)$ 
49-63\%. Menurut Barham et al. (2005), sapi betina harus memiliki kepala dan leher yang panjang. Bentuk tubuh secara keseluruhan menyudut dengan kulit yang tipis dan melipat dari tenggorokan ke arah brisket. Alderson (1999) melakukan penelitian terhadap perkembangan ukuran tubuh linear pada sapi betina umur 24 dan 60 bulan. Hasil penelitian menunjukkan bahwa perkembangan tinggi hip terjadi paling cepat, yaitu mencapai $93-94 \%$ dari ukuran tubuh pada umur 24 bulan. Dalam dada berkembang lebih lambat, yaitu mencapai $97,80 \%$ dari ukuran tubuh pada umur 60 bulan. Panjang tulang kaki mencapai ukuran penuh pada umur 12 bulan.

Pengukuran morfometrik pada kedua bangsa sapi betina menghasilkan ukuran sumbu tubuh, yaitu tulang cervicalis, thoraxic dan sacral yang berbeda nyata (Tabel 3). Tulang scapulla, jarak antar tulang ischium, dan jarak antar tulang coxae-ischium pada kedua bangsa sapi tersebut juga menghasilkan perbedaan yang nyata. Tulang cervicalis, sacral dan scapulla pada sapi betina Limousin memiliki rataan yang lebih tinggi, sedangkan nilai rataan tulang thoraxic, tinggi badan, jarak antar tulang ischium dan jarak antar coxae-ischium lebih tinggi pada sapi betina FH.

Hasil penelitian menunjukkan bahwa sapi $\mathrm{FH}$ merupakan sapi yang bertubuh jenjang, memiliki tulang rusuk yang panjang dengan dada yang dalam (yang menunjukkan bahwa proporsi organ dalam sapi FH lebih tinggi), dan merupakan sapi yang memiliki lokomosi yang lebih baik dari sapi Limousin. Selain itu, sapi FH memiliki pertulangan yang lebih lebar pada bagian belakang tubuh (jarak coxae, ischium, dan coxae-ischium) dibandingkan sapi Limousin dikarenakan sapi FH merupakan bangsa tipe perah dan bagian tubuh tersebut berfungsi sebagai penopang ambing. Menurut Barham et al. (2005), sapi betina harus memiliki tulang coxae, ischium dan jarak antar coxae-ischium yang lebih panjang, lebar dan dalam yang dapat berfungsi untuk memudahkan dalam melahirkan. Menurut Shimizu et al. (1984), seksual dimorfisme terdapat pada tulang pelvis. Hal ini dikarenakan fungsi dari tulang tersebut yang lebih berperan pada betina.

Sapi Limousin memiliki kriteria sapi tipe pedaging yang baik, yang ditandai dengan memiliki sumbu tubuh yang lebih panjang, konformasi tubuh bagian depan berkembang baik, dan memiliki bagian rump yang lebih baik dari sapi FH. Menurut Alderson (1999), sapi Limousin merupakan sapi tipe pedaging yang memproduksi kualitas daging yang tiggi, dengan flavor yang baik, rendah lemak, dan memiliki marbling yang baik. Shimizu et al. (1984) menambahkan bahwa bentuk tubuh sapi tipe pedaging berbeda dengan tipe perah. Bentuk tubuh merupakan hal penting dalam penilaian komposisi karkas, khususnya pada tipe pedaging. Perbedaan bentuk tubuh tersebut merupakan hasil dari perbedaan tingkat pertumbuhan antar individu selama masa pertumbuhan yang dapat dipicu oleh perubahan fisiologi dan efisiensi ekonomi.

Frame Score Sapi FH dan Limousin Betina

Frame score (FS) dapat digunakan untuk menggambarkan ukuran kerangka tubuh sapi. FS juga dapat dijadikan sebagai dasar untuk seleksi ternak karena dapat mengidentifikasi ukuran saat mencapai dewasa. Ukuran kerangka tubuh dapat diukur dari panjang tulang tertentu atau tinggi tubuh dan tinggi hip. EAAP dan FAO menggunakan tinggi tubuh sebagai indikator utama dalam penentuan tipe sapi (Alderson 1999). BIF merekomendasikan metode pengukuran tinggi untuk FS dilakukan secara lurus pada titik hip sampai permukaan tanah dengan posisi keempat kaki sejajar dan seimbang pada umur sapi 5-21 bulan (BIF 2002). Nilai FS berada pada kisaran 1-9, semakin kecil nilai FS menunjukkan bahwa sapi tinggi tubuh sapi lebih pendek pada umurnya dan cenderung akan mencapai dewasa lebih cepat. Erchols (2011) mengestimasi kandungan lemak pada ternak yang memiliki perbedaan FS dan bobot tubuh. Bobot dewasa tubuh pada sapi yag berbeda ukuran tubuhnya tercapai saat kandungan lemak tubuh mencapai $34-37 \%$. Perbedaan bangsa sapi dapat menyebabkan keragaman ukuran kerangka tubuh dan jumlah sel otot (Hammond 1961). Frame score sapi FH dan Limousin betina pada penelitian ini ditunjukkan pada Tabel 3.

Field dan Taylor (1999) menyebutkan bahwa nilai FS untuk sapi betina optimum pada 4-6. Hasil pengukuran terhadap nilai FS sapi FH dan Limousin betina berkisar antara 5-6. Nilai FS 5 berarti ukuran tubuh sapi di atas rata-rata, hal ini berarti sapi tersebut memiliki ukuran kerangka sedikit lebih besar dari rata-rata, memiliki tulang yang panjang dan perdagingan yang panjang dan dalam yang ditunjukkan oleh otot yang melekat pada bagian lengan depan. FS dengan nilai 6 menunjukkan bahwa sapi memiliki pertumbuhan yang besar, tubuh yang panjang, kaki yang tinggi, memiliki otot yang lebih lembut dari ukuran rata-rata dan memiliki ukuran dewasa tubuh yang lebih besar (Erchols 2011). Hasil penelitian menunjukkan bahwa sapi FH memiliki ukuran tubuh (FS) yang lebih besar daripada sapi Limousin, namun bobot badan sapi Limousin lebih tinggi daripada FH. Hal ini sesuai degan Cundiff dan Gregory (1999) yang menyebutkan bahwa ukuran tubuh sapi FH lebih tinggi daripada sapi Limousin. Penelitian mengenai hubungan antara FS dengan bobot tubuh masih sangat terbatas. Pada nilai FS yang sama bobot tubuh sangat beragam, hal ini disebabkan oleh deposisi otot yang melekat pada kerangka tubuh sapi. Menurut Hammack dan Gill (2009), bobot sapi jantan dewasa lebih tinggi 55-60\% daripada betina pada nilai FS yang sama.

Bobot badan yang tinggi pada sapi Limousin dan frame size yang lebih besar pada sapi FH dapat disebabkan oleh perbedaan fungsi dari kedua bangsa tersebut, dimana sapi Limousin berfungsi sebagai ternak pedaging, sedangkan sapi FH merupakan ternak perah. Menurut Campbell et al (2005), perbedaan bentuk dan fungsi (tipe) dari bangsa tertentu merupakan hasil dari seleksi. Perbedaan tersebut secara umum terlihat dari bentuk tubuhnya. Bangsa sapi perah telah diseleksi dari produksi susunya yang tinggi dan melebihi kebutuhan anaknya sehingga nutrisi yang masuk ke dalam tubuh tidak terdeposisi menjadi otot, sedangkan pada sapi Limousin yang memiliki ukuran kerangka tubuh yang lebih rendah lebih efisien dalam menghasilkan persentase karkas yang tinggi. Menurut Troxel et al. (2006), frame size berhubungan dengan potensi pertumbuhan, periode finishing dan bobot potong. Frame size dijadikan indikator untuk 
memperkirakan pertumbuhan, nutrisi yang dibutuhkan pada sapi dan menggambarkan feed intake pada ternak sapi. Berdasarkan hasil penelitian Roviki et al. (2014), sapi yang memiliki frame size lebih tinggi menghasilkan bobot potong yang lebih tinggi namun presentase karkas yang tidak berbeda nyata. Sapi yang memiliki frame size yang tinggi juga tidak efisien secara ekonomi karena membutuhkan biaya pemeliharaan yang lebih tinggi karena konsumsi pakannya lebih tinggi.

Sapi perah memiliki persentase karkas yang lebih rendah dan rasio otot tulang yang lebih rendah daripada sapi tipe pedaging (Campbell et al. 2005). Keane (1993) telah melakukan penelitian pada berbagai bangsa sapi untuk mengetahui komposisi otot, tulang, dan lemak pada sapi jantan dengan bobot karkas $280 \mathrm{~kg}, 340 \mathrm{~kg}$ dan $400 \mathrm{~kg}$. Pada sapi FH rataan rasio otot tulang dan lemaknya masingmasing adalah $59,20 \%, 18,33 \%$, dan $22,47 \%$, sedangkan pada sapi Limousin masing-masing adalah 63,30\%, $16,90 \%$, dan 19,50\%. Hasil tersebut menunjukkan bahwa sapi FH memiiki proporsi tulang dan lemak yang lebih tinggi daripada sapi Limousin.

\section{Hubungan Antara Ukuran Tubuh dengan Estimasi Deposisi Perdagingan pada Sapi FH dan Limousin Betina}

Berdasarkan data pada Tabel 3 dapat diasumsikan deposisi perdagingan dan perlemakan pada karkas yang dihasilkan kedua bangsa sapi. Deposisi perdagingan ini dapat dilihat dari potongan komersial karkas sapi (Gambar $3)$.

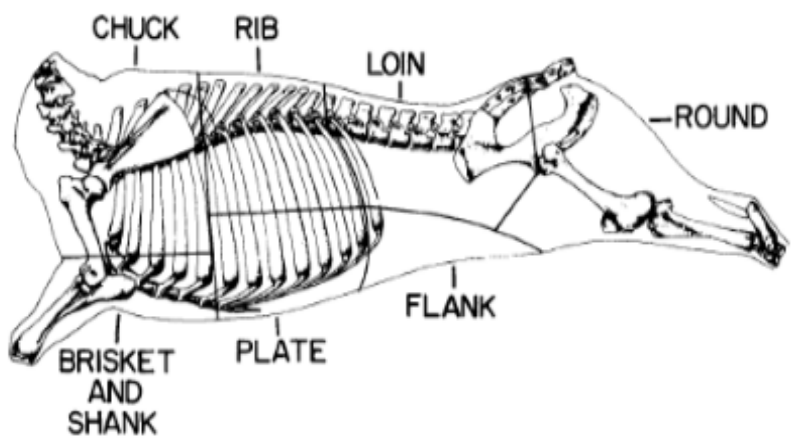

Gambar 3. Potongan komersial karkas sapi

Sapi Limousin memiliki rataan nilai cervicalis, lumbar, sacral, scapula, femur dan tibia-fibula yang lebih tinggi. Hal ini dapat menunjukkan bahwa deposisi perdagingan/perlemakan pada bagian potongan daging chuck, loin dan round lebih tinggi daripada sapi FH. Hal ini sesuai dengan pendapat Barham et al. (2005) yang menyebutkan bahwa bagian neck pada sapi tipe pedaging lebih panjang, yang merupakan indikator dari pertumbuhannya. Selain itu, bagian loin, rump, dan round juga panjang dan lebar, yang menyebabkan bagian sumbu tubuh sapi tipe pedaging lebih panjang. Sapi tipe pedaging juga memiliki proporsi yang sedang pada bagian flank dan brisket. Tulang thoraxic dan radius ulna sapi FH lebih tinggi daripada sapi limousin, proporsi ribs dan brisket lebih tinggi pada FH. Menurut Barham et al. (2005), sapi betina memiliki deposit lemak yang lebih banyak pada bagian brisket, bagian bawah tubuh, dan pada ribs serta bagian punggung dibandingkan pada sapi jantan. Sapi Limousin merupakan sapi penghasil daging dengan kualitas yang tinggi, memiliki persentase karkas mencapai $62-65 \%$ yang terdiri dari otot di atas $75 \%$, rendah lemak, dan memiliki sistem kerangka yang baik.

Hammond mengemukakan bahwa perubahan proporsi otot bereaksi terhadap perubahan proporsi dan sudut tulang yang terbentuk, yang mengikuti fungsi dari otot dan tulang tersebut (Berg dan Butterfield 1976). Peningkatan panjang tulang menyebabkan peningkatan produksi regangan otot pasif, dengan demikian perbedaan pertumbuhan tulang dapat menjelaskan perbedaan pertumbuhan otot yang terbentuk. Menurut Berg dan Butterfield (1976), terdapat 9 kelompok otot standar pada sapi, diantaranya:

Kelompok 1: Otot yang terdapat pada bagian pelvis yang muncul dari os coxae

Kelompok 2: Otot yang muncul dari bagian tengah distal dari femur, dari tibia, atau dari fibula

Kelompok 3: Otot yang berkembang di sekitar tulang belakang pada bagian thorax dan lumbar

Kelompok 4: Otot di sekitar dinding perut

Kelompok 5: Otot yang terdapat pada bagian thoraxic yang muncul dari scapula atau pada setengah bagian depan tubuh dari humerus

Kelompok 6: Otot yang terdapat pada bagian thoraxic yang muncul pada setengah bagian belakang tubuh dari humerus, dari radius atau dari ulna

Kelompok 7: Otot pada thorax yang menempel pada bagian thoraxic

Kelompok 8: Otot pada bagian leher yang menempel pada bagian thoraxic

Kelompok 9: Otot yang terdapat pada bagian leher dan thorax

'expensive group': gabungan antara otot pada kelompok 1, 3 , dan 5 .

Berdasarkan hasil pengukuran dimensi tubuh sapi FH dan Limousin betina, dapat dikatakan bahwa sapi Limousin memiliki potensi perkembangan otot yang lebih baik pada kelompok 1, 2, 3, 5, 8, 9, dan memiliki proporsi 'expensive group' yang lebih baik daripada sapi FH. Sapi FH memiliki potensi perkembangan otot yang baik pada kelompok 1, 4, 6, 7, dan 9. Namun pada sapi FH betina, bagian kelompok otot 1 tidak berkembang baik, karena memiliki fungsi fisiologis tersendiri, yaitu sebagai penghasil susu sehingga kondisi bagian pelvis sapi tersebut tidak memiliki perkembangan otot yang baik.

Perbedaan utama antar bangsa sapi tipe perah dan daging terletak pada ciri dari pendistribusian lemak di antara depot lemaknya. Karkas tipe perah cenderung memiliki proporsi lemak internal yang lebih tinggi dan proporsi lemak subkutan yang lebih rendah dibanding dengan tipe daging (Field dan Taylor 1999). Lemak memiliki pengaruh yang besar dalam membentuk karkas. Lemak subkutan memberikan pengaruh yang lebih besar, 
sedangkan lemak intermuskular menyebabkan otot lebih besar (Field dan Taylor 1999). Deposisi lemak yang tinggi dapat meningkatkan bobot hidup. Deposisi lemak yang tinggi terdapat pada bagian flank dan brisket, juga pada sepanjang loin dan rib. Deposisi lemak yang rendah terdapat pada bagian lengan depan dan paha bagian depan. Jones et al. (1980) melakukan penelitian mengenai proporsi lemak pada potongan komersial sapi tipe pedaging dan perah. Hasil penelitian tersebut menunjukkan bahwa lemak yang tinggi terdeposisi pada bagian brisket, flank, chuck, loin dan round.

\section{Hubungan Antara Ukuran Tubuh dengan Tingkah Laku Lokomosi Sapi FH dan Limousin Betina}

Panjang tulang pada alat gerak dapat menentukan tingkah laku lokomosi dari hewan tersebut (Gould 1966); Habib dan Ruff 2008; Barham et al. 2005). Berdasarkan data hasil penelitian pada Tabel 2 dapat dilihat bahwa alat gerak depan (tulang radius-ulna dan metacarpus) pada sapi FH lebih tinggi daripada sapi Limousin. Tulang radius-ulna berfingsi sebagai alat gerak yang lebih fleksibel, memiliki perputaran terbatas, dan penunjang dalam pergerakan serta menentukan kemampuan kecepatan gerak (Camillo 2013). Hal ini dapat membuktikan bahwa pada sapi FH memiliki pergerakan atau daya jelajah yang lebih baik daripada sapi Limousin. Kaki yang kecil, lemah, dan melengkung dapat membuat pergerakan menjadi lambat dan terbatas (Barham et al. 2005).

Alat gerak merupakan komponen non karkas yang dapat menyebabkan berkurangnya proporsi karkas. Dengan demikian dapat disebutkan bahwa proporsi non karkas pada sapi FH lebih tinggi daripada sapi Limousin. Hal ini sesuai dengan hasil penelitian Keane (2011). Keane (2011) melakukan penelitian dengan membandingkan karakteristik karkas antara sapi perah dengan sapi pedaging. Hasil penelitian tersebut menunjukkan bahwa pada sapi perah memiliki proporsi organ eksternal (kepala, kaki dan ekor), proporsi lemak offal dan saluran pencernaan yang lebih tinggi daripada sapi pedaging. Selain itu, bangsa sapi perah juga secara keseluruhan memiliki proporsi non karkas yang lebih tinggi dan persentase karkas dingin yang lebih rendah daripada sapi tipe pedaging.

\section{KESIMPULAN}

Metode pengukuran melalui citra digital tidak berbeda nyata dengan pengukuran secara manual, sehingga dapat diaplikasikan untuk pengukuran dimensi linear panjang tubuh ternak. Sapi FH betina memiliki ukuran tubuh yang lebih besar daripada sapi Limousin, namun bobot badan sapi Limousin lebih tinggi yang disebabkan oleh perbedaan fungsi dari kedua sapi tersebut.

\section{UCAPAN TERIMA KASIH}

Penulis menyampaikan terima kasih kepada DIKTI atas beasiswa BPP-DN yang telah diterima. Terima kasih juga disampaikan kepada Kepala dan Staf Balai Embrio Ternak (BET) Cipelang, Bogor, yang telah memberikan izin dan membantu pelaksanaan penelitian ini.

\section{DAFTAR PUSTAKA}

BIF (Beef Improvement Federation). 2002. Guidelines for Uniform Beef Improvement Programs. Ed ke-8. Beef Improvement Federation. Kansas State University, Manhattan.

DSN (Dewan Standarisasi Nasional). 1992. Sapi Perah Bibit SNI 01-2735-1992. Dewan Standarisasi Nasional, Jakarta.

Allaby, M. 1999. A Dictionary of Zoology. Oxford Univ. Pr, Oxford.

Anggorodi, R. 1979. Ilmu Makanan Ternak. Gramedia Pr, Jakarta.

Barham, B., S. T. Jones, \& T. R. Troxel. 2005. An Analysis of Beef Cattle Conformation. University of Arkansas, United States.

Berg, R. T., \& R. M. Butterfield. 2005. New Concept of Cattle Growth. Sydney University Pr, Sydney.

Blakely, J., \& D. H. Bade. 1991. Ilmu Peternakan. Ed ke-4. Srigandono B, penerjemah. Yogyakarta (ID): UGM Pr. Terjemahan dari: Animal Science.

Budianita, E., Jasril, \& L. Handayani. 2015. Implementasi pengolahan citra dan klasifikasi K-Nearest Neighbour untuk membangun aplikasi pembeda daging sapi dan babi. J Sci Tek dan Industri. 12(2):242-247.

Camillo,V.D.2013. Thebonebasics [Internet][Diunduh2015 20 Oktober]. Tersedia pada: http://www.entomology. cornell.edu/cals/entomology/extension/outrea ch/ upload/SarahUCudneyULocomotionUanatomy.pdf.

Campbell, J. R., M. D. Keneal, K. L. Campbell, J. Campbell, M. Kenealy, \& K. Campbell. 2005. Animal Sciences: The Biology, Care, and Production of Domestic Animals. Ed ke-4. McGraw-Hill Pub, New York.

Chamdi, A. N. 2005. karakteristik sumber daya genetik ternak sapi bali (Bos-Bibos banteng) dan alternative pola konservasinya. Biodiversitas. 6(1): 70-75.

Cundiff, L. V., \& K. E. Gregory. 1999. What is systematic crossbreeding? Proceedings of Cattlemens College, National Cattlemens Beef Association, Charlotte, NC.

Enchols, A. C. 2011. Relationship among lifetime measures of growth and frame size for commercial beef females in pasture-based production system in the Appalachian region of the United States [Tesis]. United States (US): Virginia Polytechnic Institute and State University.

Ensminger, M. E. 1993. Dairy Cattle Science. 3rd Ed. Interstate Publishers, Inc. Denville, Illinois.

Field, T. G., \& R. E. Taylor. 1999. Beef Production and Management Decisions. Ed ke-3. Pearson Prentice Hall, New Jersey.

Field, T. G., \& R. E. Taylor. 2002. Beef Production and Management Decisions. Ed ke-4. Pearson Prentice Hall, New Jersey.

Field, T. G., \& R. E. Taylor. 2008. Scientific Farm Animal Production. Ed ke-9. Pearson Prentice Hall, New Jersey.

Firdausi, A., T. Susilawati, M. Nasich, \& Kuswati. 2012. Pertambahan bobot badan harian sapi brahman cross pada bobot badan dan frame size yang berbeda. J Ternak Tropika. 13(1):48-62. 
Fisher, A. V. 1975. The accuracy of some body measurements on live beef steers. Livestock Prod Sci. 2:357-366.

Frandson, R. D., W. L. Wilke, \& A. D. Fails. 2009. Anatomy and Physiology of Farm Animals. 7th Ed. Wiley-Blackwell Pub, Colorado.

Gould, S. J. 1966. Allometry and size in ontogeny and phylogeny. Biol. Rev. 41:587-640.

Habib, M. B., \& C. B. Ruff. 2008. The effects of locomotion on the structural characteristics of avian limb bones. Zoological Journal of the Linnean Society. 153(3):601624.

Hafez, E. Z. E., \& I. A. Dyer. 1969. Animal Growth and Nutrition. Philadelphia: Lea \& Febiger Pub.

Hafid, H., \& R. Priyanto. 2006. pertumbuhan dan distribusi potongan komersial karkas sapi Australian Commercial Cross dan Brahman Cross hasil penggemukan. Med. Pet. 29: 63-69.

Hammack, S. P., \& R. J. Gill. 2009. Texas adapted genetic strategies for beef cattle $\mathrm{x}$ : rame score, frame size, and weight. Agrilife Extention. 1-4.

Jones, S. D. M., M. A. Price, \& R. T. Berg. 1980. Fat distribution among the wholesale cuts. J Anim Sci. 60:851-856.

Keane, M. G. 2011. Relative tissue growth patterns and carcass composition in beet cattle. Netherland (NL): Teagasc, Occasional Series No. 7, Grange Beef Research Centre.

Kidwell, J. F., P. W. Gregory, \& H. R. Guilbert. 1952. A genetic investigation of allometric growth in Hereford cattle. Genetics. 37:158-172.

Kiswanto. 2012. Identifikasi citra untuk mengidentifikasi jenis daging sapi dengan menggunakan transformasi wafelet haar [Tesis]. Semarang (ID): Universitas Diponegoro.

Lasfeto, D. B., A. Susanto, \& A. Agus. 2008. Aplikasi pengolahan citra untuk estimasi bobot badan ternak sapi. Buletin Peternakan. 32(3):167-176.

Lawrence, T. L. J., V. R. Fowler, \& J. Vovakofski. 2012. Growth of Farm Animals. Ed ke-3. CABI Pub, Cambridge.

Lawrence, T. L. J., \& V. R. Fowler. 2002. Growth of Farm Animals. Ed ke-2. CABI Pub, Oxon.

Meyn, K. 1991. The Contribution of European Cattle Breeding to Cattle Production in The Third World. Animal Research and Development. Vol 34. Institute for Wissen Schaftliche Zusam Menarbeit. Federal Republic of Germany.
Munoz-Munoz, F., \& D. Perpinan. 2010. Measurement error in morphometric studies: comparison between manual and computerized methods. Ann Zool Fennici. 47:46-56.

Natasasmita, A., \& K. Mudikdjo. 1979. Beternak Sapi Pedaging. Fakultas Peternakan IPB, Bogor.

Pabiou, T., W. F. Fikse, P. R. Amer, A. R. Cromie, A. Nasholm, \& D. P. Berry. 2011. Genetics variation in wholesale Irish carcass cuts predicted from video image analysis. Animal. 5(11):1720-1727.

Pane, I. 1986. Pemuliaan Ternak Sapi. Cetakan Pertama. PT. Gramedia, Jakarta.

Phillips, C. J. C. 2010. Principles of Cattle Production. Ed ke-2. CABI Pub, Wallingford.

Sampurna, I. P., \& I. K. Suatha. 2010. Pertumbuhan alometrik dimensi panjang dan lingkar tubuh sapi bali jantan. J Veteriner. 11(1):46-51.

Schimidt-Nielsen, K. 1984. Scaling: Why is Animal Size so Important? Cambridge University Press, Cambridge.

Schofield, C. P. 1990. Evaluation of image analysis as a means of estimating the weight of pig. J Agric Eng Research. 47:287-296.

Shimizu, H., T. Yamadate, T. Awata, J. Ueda, \& Y. Hachinohe. 1984. A modification in skeletal bone growth by the selection for boy weight in mice. J. Fak. Hokkaido Univ. 62(1): 36-54.

Soeparno. 2005. Ilmu Teknologi Daging. Ed Ke-4. UGM Pr, Yogyakarta.

Stajnko, D., M. Brus, \& M. Hocevar. 2008. Estimation of bull weight through thermographically measured body dimensions. Comp and Electrons in Agr. 61:233-240.

Steel, R. G. D., \& J. H. Torrie. 1991. Prinsip dan Prosedur Statistika. Terjemahan: Bambang S. PT Gramedia Pustaka Utama, Jakarta.

Tasdemir, S., A. Urkmez, \& S. Inal. 2011. Determination of body measurement on the Holstein cows using digital image analysis and estimation of live weight regression analysis. Comp and Electrons in Agr. 76:189-197.

Tillman, A. D. H., S. Hartadi, S. Reksohadiprojo, S. Prawirokusumo, \& Lebdosoekojo. 1991. Ilmu Makanan Ternak Dasar. UGM Pr, Yogyakarta.

Thomas, V. M. 1991. Beef Cattle Production. Wafeland Pr, Montana University.

Williams, I. H. 1982. A Course Manual in Manual in Nutrition and Growth. Australian ChoncellorsCommitte, Melbourne. 